Volume 2 Issue 2 (2018) Pages 270 - 274

\title{
Preoperational Development of Eearly Childhood with Insectarium Media
}

\author{
Ranny Fitria Imran ${ }^{1 凶}$, Novi Ade Suryani ${ }^{2}$ \\ Prodi PG-PAUD, FKIP, Universitas Dehasen Bengkulu, Indonesia
}

\begin{abstract}
Golden age is an investment for the future that is at the age of 2-7 years. This study, trains child development at the pre-operational stage of early childhood because children are still thinking realistic. To train early childhood development, this study uses insect-resistant media, which serves to introduce early childhood to surrounding insects. The research method used is the Pre Test Post Test Group Design. The subjects of this study were children of group B of Rafa PAUD in Bengkulu City. Data collection in this study is the initial test (pretest) and final test (posttest). From the results of the pretest of children's ability, there are still undeveloped children and the results of the post-test there are 7 well-developed children. The conclusion of this study is the use of insect-resistant media (insectarium) influences the preoperational thinking abilities of early childhood group B PAUD Bengkulu City
\end{abstract}

Keywords: Preoperational for Early Childhood, Insectarium.

\begin{abstract}
Abstrak
Usia keemasan anak (golden age) merupakan investasi bagi masa depan yaitu pada usia 2-7 tahun. Penelitian ini bertujuan untuk melatih perkembangan anak pada tahapan praoperasional anak usia dini karena agar anak dapat berpikir nyata. Untuk melatih perkembangan anak usia dini maka penelitian ini menggunakan media awetan serangga, yang berfungsi untuk mengenalkan anak usia dini pada serangga sekitar. Metode penelitian yang digunakan adalah Pre Test Post Test Group Design. Subyek penelitian ini adalah anak kelompok B PAUD Rafa Kota Bengkulu. Pengumpulan data pada penelitian ini adalah tes awal (pretest) dan tes akhir (posttest). Dari hasil pretest kemampuan anak didapatkan masih ada anak yang belum berkembang dan hasil post tes terdapat 7 orang anak yang berkembang dengan baik. Kesimpulan dari penelitian ini adalah penggunaan media awetan serangga (Insektarium) berpengaruh pada kemampuan berpikir praoperasional anak usia dini kelompok B PAUD Kota Bengkulu.
\end{abstract}

Kata Kunci: praoperasional anak usia dini, insektarium,

@ Jurnal Obsesi Prodi PG-PAUD FIP UPTT 2018

$\triangle$ Corresponding author :

Address : J1. Jeruk No.12 Lingkar Timur Bengkulu

Email : rannyimran@gmail.com

ISSN 2356-1327 (Media Cetak)

ISSN 2549-8959 (Media Online) 


\section{PENDAHULUAN}

Masa perkembangan anak usia dini yang dimulai dari usia 2-7 tahun merupakan tahap perkembangan kognitif yaitu tahapan pra operasional. Kemampuan menerima rangsang anak sudah mulai berkembang, akan tetapi masih sangat terbatas. Pembelajaran pada anak usia dini diperlukan untuk kehidupannya dimasa mendatang. Keberhasilan proses pendidikan pada masa usia dini tersebut memiliki dampak terhadap pengembangan kemampuan untuk berbuat dan belajar pada masa-masa berikutnya.(Hayati, Kurniawati, \& Witarsa, 2018)

Salah satu kemampuan yang dikembangkan pada anak usia dini adalah kemampuan bahasa. Berbagai aspek perkembangan yang dapat dikembangkan dalam pendidikan anak usia dini, yaitu fisik maupun psikis yang meliputi perkembangan intelektual atau kognitif, bahasa, motorik, dan sosio-emosional. (Yanti \& Nurwidaningsih, 2018)

Kemampuan bahasa anak juga sudah mengalami perkembangan yaitu bisa memahami dan mengungkapkan melalui bahasa, sedangkan kemampuan berpikir abstrak, kesadaran akan waktu dan ruang masih terbatas (Piaget dalam Salimah, 2011).

Berdasarkan teori yang dikemukakan Piaget, tahapan perkembangan anak dibagi dalam 4 tahapan yaitu, tahapan sensorimotor (usia 0-2 tahun), tahapan pra operasional (usia 2-7 tahun), tahapan konkret operasional (usia 7-11 tahun), tahapan formal operasional (usia 1115 tahun). Pada usia 2-7 tahun anak berada dalam periode perkembangan kognitif pra operasional dimana pada usia ini anak memiliki penguasaan sempurna akan objek permanen yang dimiliki. Kemampuan berpikir anak usia dini yang masih terbatas dapat dilatih dengan berbagai cara, yaitu dengan menggunakan media gambar seri (Salimah, 2011). Sedangkan pada penelitian ini menggunakan media awetan serangga (insektarium) dan gambar yang ada dalam buku pelajaran. Menurut penelitian Riyanto (2009) yaitu mengenai penilaian insektarium sebagai media pembelajaran materi klasifikasi serangga pada mata kuliah entomologi. Lalu terdapat juga hasil penelitian Primiani (2010) yaitu meningkatkan aktifitas dan prestasi belajar biologi dengan media herbarium dan insektarium.

Media awetan dipilih karena pada tahap Praoperasional ini anak-anak belum dapat berpikir secara abstrak untuk mengenalkan anak pada hewan serangga yang ada disekitar lingkungan mereka. Insekitarium merupakan jenis media pembelajaran realia, yaitu alat bantu visual yang dapat memberikan pengalaman langsung kepada anak. Realia ini menggunakan model dan objek nyata dari hewan yaitu serangga disekitar (Zaman, 2010). Selain itu dapat memungkinkan anak untuk melakukan eksplorasi terhadap berbagai benda, baik benda hidup maupun benda mati (Aisyah, 2017).

Serangga ini dipilih karena merupakan hewan yang banyak ditemukan di Indonesia. Indonesia merupakan kawasan tropik yang mempunyai iklim yang stabil dan secara geografi adalah negara kepulauan yang terletak diantara dua benua, yaitu Asia dan Australia. Menurut data Bappenas (1993) Indonesia memiliki jumlah keanekaragaman Serangga dengan jumlah 250.000 jenis atau sekitar $15 \%$ dari jumlah jenis Biota yang diketahui di Indonesia.

Dari observasi awal yang telah dilakukan peneliti, didapatkan hasil bahwa penggunaan media gambar masih belum efektif dilakukan dalam tema "Binatang", sehingga dengan menggunakan media awetan serangga (insektarium) ini maka dapat membuktikan bahwa daya ingat anak usia dini menjadi semakin baik dengan adanya media yang langsung dapat dilihat dan disentuh. Kemudian dengan menggunakan media awetan serangga (insektarium) akan menambah ketertarikan anak dalam proses pembelajaran.

Media awetan dipilih karena pada tahap Praoperasional ini anak-anak belum dapat berfikir secara abstrak, sehingga dibantu dengan media awetan (Insektarium) untuk mengenalkan anak pada hewan 
serangga yang ada disekitar lingkungan mereka. Insekitarium merupakan jenis media pembelajaran realia, yaitu alat bantu visual yang dapat memberikan pengalaman langsung kepada anak. Realia ini menggunakan model dan objek nyata dari hewan yaitu serangga disekitar. (Zaman, 2010).

Tujuan dari penelitian ini adalah untuk melatih perkembangan praoperasional anak usia dini dalam pengenalan hewanhewan di sekitar khususnya serangga. Oleh karena itu penelititan ini memiliki manfaat untuk pengenalan anak terhadap hewanhewan serangga disekitar yang juga dapat dijadikan sebagai media pembelajaran. Dengan pengenalan hewan serangga sekitar dapat bermanfaat bagi orangtua untuk menjelaskan kepada anak serangga yang memiliki sengat seperti lebah dan yang tidak menyengat seperti kupu-kupu.

\section{METODE}

Jenis penelitian ini adalah eksperimen. Pengumpulan data pada penelitian ini adalah dengan menggunakan tes awal (pretest) dan tes akhir (post test). Tes ini dilakukan untuk melihat perkembangan anak menggunakan media gambar dan menggunakan media awetan serangga (insektarium).

Penelitian ini berlangsung dari bulan Februari hingga Maret 2018 di PAUD Rafa Kota Bengkulu. Kelas yang digunakan pada kelompok B berjumlah 28 orang sebanyak 18 orang perempuan dan 10 orang laki-laki. Alat yang digunakan dalam penelitian ini adalah jaring (net) penangkap serangga, killing bottle, kotak insekta, jarum pentul, sterofom, plastik mika, kuas, jarum suntik, dan kapur barus. Bahan yang digunakan eter atau alkohol 70\% dan serangga sekitar.

\section{HASIL DAN PEMBAHASAN}

Berdasarkan hasil observasi awal dan akhir perkembangan praoperasional anak usia dini dengan media awetan serangga (Insektarium) PAUD Kota Bengkulu diperoleh data yang dapat dilihat pada Tabel 1 dibawah ini:
Tabel 1. Data Hasil Pretest Menggunakan Media Gambar Serangga

\begin{tabular}{|c|c|c|}
\hline Kategori & Frekuensi & Persentase (\%) \\
\hline BB & 5 & 17,9 \\
\hline MB & 13 & 46,4 \\
\hline BSH & 8 & 28,6 \\
\hline BSB & 2 & 7,1 \\
\hline Jumlah & 28 & 100 \\
\hline
\end{tabular}

Dari hasil pretest yang dilakukan menggunakan media gambar, masih didapatkan siswa yang belum berkembang sesuai harapan. Hal ini dikarenakan media kartu gambar yang digunakan masih kurang jelas dalam menyajikan warna dan bentukbentuk binatang dalam hal ini serangga sekitar. Hal ini terlihat dari siswa yang belum bisa menyocokkan antara gambar dan tulisan disebelahnya.

Terdapat 2 orang siswa yang berkembang sangat baik. Hal ini ditunjukkan dengan sudah bisa menyocokkan antara kartu gambar dan tulisan yang berada disebelahnya.

Tabel 2. Data Hasil Posttest setelah Menggunakan Media Awetan Serangga (insektarium)

\begin{tabular}{|c|c|c|}
\hline Kategori & Frekuensi & Persentase (\%) \\
\hline BB & - & - \\
\hline MB & 7 & 25 \\
\hline BSH & 14 & 50 \\
\hline BSB & 7 & 25 \\
\hline Jumlah & 28 & 100 \\
\hline
\end{tabular}

Hasil posttes setelah menggunakan media awetan serangga didapatkan bahwa siswa mulai berkembang, berkembang sesuai harapan dan berkembang dengan baik. Hal ini dikarenakan siswa dapat berinteraksi langsung dengan awetan serangga yang dimasukkan ke dalam kotak insektarium. Siswa dapat mengamati dan melatih keterampilan motorik halusnya agar lebih mengenali serangga-serangga sekitar.

\section{PEMBAHASAN}

Pada penelitian ini berfokus pada kegiatan pembelajaran untuk membantu melatih kemampuan praoperasional anak usia dini dengan menggunakan media awetan serangga (insektarium). Penggunaan insektarium merupakan media yang dapat 
langsung dilihat dan dibawa kedalam kelas. Hal ini sesuai dengan yang dinyatakan oleh Zaman (2010) bahwa realia dalam hal ini berupa media awetan serangga (insektarium) menggunakan model dan objek nyata dari hewan yaitu serangga disekitar. Sehingga dapat membantu melatih perkembangan praoperasional anak usia dini dalam berpikir nyata suatu benda atau makhluk hidup.

$$
\text { Pada hasil pretest dengan }
$$

menggunakan media gambar serangga masih terdapat siswa yang belum berkembang sebanyak 5 orang. Hal ini dikarenakan penggunaan media gambar yang kurang jelas dalam hal warna dan bentuknya. Ada beberapa anak yang belum mengetahui perbedaan gambar lebah dan tawon. Hal ini disebabkan warna dan bentuk tawon yang hampir serupa pada gambar yang disajikan. Serangga ini memiliki kemiripan sehingga dibutuhkan bimbingan dari guru untuk dapat membedakan keduanya.

Setelah dilakukan posttest dengan menggunakan media awetan serangga (insektarium) siswa sudah bisa membedakan gambar-gambar serangga. Siswa diajak untuk dapat mengenali dan mengingat nama serangga yang ada pada insektarium. Pada kegiatan ini siswa langsung melakukan interaksi dengan melihat bentuk nyata dari seranggaserangga sekitar. Saat menggunakan insektarium ini, siswa langsung dapat menyebutkan nama serangga yang ada didalam kotak insektarium. Kemudian siswa tanpa bantuan guru dapat melakukan kegiatan menyocokkan antara gambar dan tulisan yang ada disebelahnya. Siswa yang belum berkembang sudah mulai berkembang dengan mencoba menyocokkan gambar dan tulisan disamping gambar. Sehingga tidak ada lagi siswa yang belum berkembang, Siswa mulai berkembang, berkembang sesuai harapan dan berkembang sangat baik.

Penggunaan gambar yang ada di buku masih membutuhkan bimbingan dari guru dalam menyocokkan gambar dan tulisan. Guru harus membimbing siswa yang masih belum bisa membedakan serangga seperti lebah dan tawon. Sedangkan dengan media awetan serangga, siswa langsung dapat menyocokkan antara gambar dan tulisan dengan sendirinya. Siswa kelas B ini sudah mengenal hurufhuruf dan angka meskipun belum terlalu lancar karena kelas ini merupakan kelas persiapan memasuki usia sekolah dasar.

Sangat diperlukan kegiatan-kegiatan pembelajaran lainnya yang merangsang aktivitas kognitif anak usia dini untuk membantu melatih kemampuan berpikir abstrak. Dengan adanya media awetan serangga (insektarium) ini membantu siswa dalam melatih perkembangan praoperasional diusia 5-6 tahun. Selain serangga sekitar, tumbuhan sekitar juga dapat dijadikan koleksi untuk dibuat menjadi suatu herbarium sebagai media pembelajaran lainnya.

\section{SIMPULAN}

Hasil penelitian yang telah dilakukan dapat disimpulkan bahwa dengan menggunakan media awetan serangga (Insektarium) dapat membantu melatih perkembangan praoperasional yaitu berpikir nyata pada anak usia dini di kelompok B PAUD Kota Bengkulu.

\section{UCAPAN TERIMA KASIH}

Peneliti dan anggota peneliti mengucapkan terimakasih kepada kepala sekolah PAUD Rafa Kota Bengkulu yang telah bekerjasama dengan baik selama penelitian ini. Kemudian tidak lupa ucapan terimakasih kepada tim penangkap serangga yang telah berusaha mengumpulkan serangga-serangga sekitar sehingga dapat menjadi media awetan serangga (insektarium).

\section{DAFTAR PUSTAKA}

Aisyah. 2017. Permainan Warna Berpengaruh terhadap Kreativitas Anak Usia Dini. Jurnal Obsesi : Jurnal Pendidian Anak Usia Dini, $\mathrm{I}(2)$.

http://obsesi.or.id/index.php/obsesi 
Bappenas. 2015. Indonesian Biodiversity: Strategy and Action Plan. https://www.bappenas.go.id/files/pu blikasi_utama/Dokumen_IBSAP_20 15-2020.pdf. diakses tanggal 11 Agustus 2018

Hayati, T., Kurniawati, M., \& Witarsa, R. (2018). Meningkatkan Kemampuan Kecerdasan Visual melalui Aplikasi Paint. Jurnal Obsesi : Jurnal Pendidikan Anak Usia Dini, 2(1), 109-116.

Primiani, Novi. 2010. Meningkatkan Aktifitas dan Prestasi Belajar Biologi dengan Media Herbarium dan Insektarium. Solo: Jurnal FKIP UNS Vol. 13 No.1

Riyanto. 2009. Penilaian Insektarium sebagai Media Pembelajaran Materi Klasifikasi Serangga pada Mata Kuliah Entomologi di Program Studi Pendidikan Biologi FKIP UNSRI. Jurnal FKIP UNSRI

Salimah. 2011. Dampak Penerapan Bermain dengan Media Gambar Seri dalam Mengembangkan Keterampilan Berbicara dan Penguasaan Kosakata Anak Usia Dini. Jurnal Edisi Khusus 1

Sugiyono, 2010. Penelitian

Pendidikan. Bandung: Alfabeta

Suyitno. 2004. Penyiapan Spesimen Awetan Objek Biologi. Jurnal Biologi FMIPA UNY

Yanti, M., \& Nurwidaningsih, L. (2018). Pengaruh Percobaan Sains Anak Usia Dini terhadap Perkembangan Kognitif Anak di TK Kartika Siwi Pusdikpal Kota Cimahi. Jurnal Obsesi : Jurnal Pendidikan Anak Usia Dini, 2(1), 91-97.

Zaman, B. 2010. Media Pembelajaran Anak Usia Dini. Bandung : UPI 